\title{
Effects of chin advancement surgery in hyoid bone and tongue positions and in the dimension of the oropharynx
}

\author{
Milena Barreto de Arruda Cabral ${ }^{1}$, André Carlos de Freitas², Telma Martins de Araújo ${ }^{3}$, Nilson Pena
}

Rivail Almeida Brandão Filho ${ }^{5}$

Introduction: Advancement genioplasty has been increasingly indicated for the correction of anterior mandibular deficiency as it balances the patient's profile and generates functional changes. Objective: Thus, the aim of this study was to assess the effects of advancement genioplasty in the oropharyngeal size and in the position of the hyoid bone and tongue. Methods: The sample comprised 22 lateral cephalometric radiographs of 11 individuals who had undergone advancement genioplasty alone. Eleven of these radiographs depicted the immediate preoperative period $\left(\mathrm{T}_{0}\right)$ and the other 11 the postoperative period after at least four months $\left(\mathrm{T}_{1}\right)$. The radiographs were scanned and exported to the Radiocef Studio $2.0^{\circledR}$ software (Radio Memory Ltda., Belo Horizonte, MG, Brazil). The landmarks were then identified and automatically measured by the program. Results: The results showed statistically significant differences between the horizontal position of the hyoid bone and tongue and in the oropharyngeal size. The hyoid bone and tongue were repositioned anteriorly after surgery $(p=0.01)$, thereby increasing the dimension of the oropharyngeal airspace $(\mathrm{p}=0.01)$. Conclusions: The oropharyngeal dimension increased as the tongue base and hyoid bone were repositioned more anteriorly.

Keywords: Orthognathic surgery. Chin. Oropharynx. Hyoid bone. Tongue.

Introdução: a cirurgia de avanço de mento isolado tem sido cada vez mais indicada para a correção de deficiência anterior da mandíbula, harmonizando o perfil e gerando alterações funcionais. Objetivo: essa pesquisa teve a finalidade de avaliar os efeitos da cirurgia de avanço de mento no tamanho da orofaringe e nas posições do osso hioide e da língua. Métodos: a amostra constou de 22 radiografias cefalométricas de perfil de 11 indivíduos que se submeteram à cirurgia de mentoplastia de avanço isolada. Dessas radiografias, 11 retratavam o período imediatamente pré-cirúrgico $\left(\mathrm{T}_{0}\right)$ e 11 o pós-cirúrgico de, pelo menos, quatro meses $\left(\mathrm{T}_{1}\right)$. As radiografias foram digitalizadas e transferidas para o programa Radiocef Studio 2.0, por meio do qual foram feitas as medições entre os pontos demarcados. Resultados: verificaram-se diferenças estatisticamente significativas entre $\mathrm{T}_{0}$ e $\mathrm{T}_{1}$ quanto à posição do osso hioide e da língua no sentido horizontal e ao tamanho da orofaringe. $O$ osso hioide se apresentou posicionado mais anterior em $T_{1}(p=0,01)$, assim como a língua, aumentando o tamanho da orofaringe $(\mathrm{p}=0,01)$. Conclusão: houve aumento do espaço aéreo da orofaringe com o posicionamento mais anterior da base da língua, bem como a reposição do osso hioide anteriormente.

Palavras-chave: Cirurgia ortognática. Queixo. Orofaringe. Osso hioide. Língua.

" The patients displayed in this article previously approved the use of their radiographs.

\footnotetext{
${ }^{1}$ MSc Student in Orthodontics and Facial Orthopedics, Bahia Federal University (UFBA).

${ }^{2} \mathrm{PhD}$, Oral and Maxillofacial Surgery. Associate Professor, UFBA.

${ }^{3} \mathrm{PhD}$ and Full professor, Department of Orthodontics, UFBA.

${ }^{4} \mathrm{PhD}$ in Dental Radiology, UNICAMP.

${ }^{5} \mathrm{PhD}$ Student in TMD and Associate Professor, UFBA.
}

How to cite this article: Cabral MBA, Freitas AC, Araújo TM, Pena N, Brandão Filho RA. Effects of chin advancement surgery in hyoid bone and tongue positions and in the dimension of the oropharynx. Dental Press J Orthod. 2013 Sept-Oct;18(5):64-9.

Submitted: June 30, 2011 - Revised and accepted: December 03, 2011

" The authors report no commercial, proprietary or financial interest in the products or companies described in this article.

Contact address: Milena Barreto de Arruda Cabral Av. Araújo Pinho, $62-7^{\circ}$ andar - Canela - Salvador/BA - Brazil CEP: 40.110-150 - E-mail: cabralmilena@hotmail.com 


\section{INTRODUCTION}

Patients with dentofacial deformities increasingly seek combined orthodontic-surgical treatment. Above and beyond the esthetic issues inherent in facial deformity, functional conditions such as chewing, speech, articulation and nasal ${ }^{1}$ breathing can be compromised. Genioplasty is a surgical procedure widely used in conjunction with other orthognathic surgeries to correct transverse, vertical and sagittal imbalances of the lower third of the face. Nowadays, it is often indicated to be performed alone as it is considered a relatively simple procedure with predictable results which, when properly indicated, improves facial esthetics.

Chin hypoplasia or deficiency is one of the most frequent deformities found in the anterior region of the mandible. ${ }^{2}$ It is often seen in patients with both Angle Class II and Class I malocclusions with appropriate three-dimensional positioning of the maxillomandibular complex. For many of these cases, genioplasty is likely to be the treatment of choice. ${ }^{3}$

By means of genioplasty some deformities specific to the lower third of the face can be corrected by changing the shape and size of the mandibular symphysis, thereby improving soft tissue bone support and patient profile. ${ }^{2}$ When performed alone, it is a more conservative surgical procedure involving little morbidity and not requiring intermaxillary fixation nor a lengthy in-patient hospitalization. ${ }^{4}$

Osteotomy extends from the premolar region on one side of the mandible to the opposite side, below the apices of the teeth and the mandibular canal. The tongue muscles, including the geniohyoid and genioglossus muscles, remain attached to the osteotomized bone segment in order to ensure the blood supply necessary for the enlarged chin. ${ }^{4,5}$

The geniohyoid muscle originates from the bottom of the lower genial tubercle of the mental symphysis, extending medially to the mylohyoid region and being attached to the upper margin of the body of the hyoid bone. The mylohyoid muscle originates from the medial surface of the mandible and is attached to the anterior surface of the hyoid bone through its posterior portion. ${ }^{12}$

The genioglossus muscle originates from the genial tubercle of the mandible and has a portion of its fibers connected to geniohyoid muscle fibers so that the hyoid bone moves in tandem with the tongue and oral floor during chewing and breathing. ${ }^{11}$
In healthy individuals, the hyoid bone is situated at the level of the C3-C4 vertebrae and it is important to preserve the size of the upper airspace because it serves as an anchor for the tongue muscles. ${ }^{14}$ The distance between the hyoid bone and the mandibular plane is of approximately $12 \mathrm{~mm} .{ }^{15}$

The oropharynx is lined with lymphoid tissue and extends itself from the second through the fourth cervical vertebra, participating in the processes of swallowing and breathing. ${ }^{10}$

Dimensional changes in the airspace have been observed after surgical repositioning of the mandible and maxilla ${ }^{6,7,8}$ as well as changes in the position of the hyoid bone, tongue and head. ${ }^{9}$ Previous studies have shown increases in oropharyngeal dimensions during mandibular advancement surgery and have recognized this surgical procedure as one of the most successful in the treatment of oropharyngeal space deficiency. ${ }^{7,16,17}$ Mandibular advancement pushes the geniohyoid and genioglossus muscles forward, causing an anterior movement of the tongue base and hyoid bone, consequently increasing posterior airspace. ${ }^{18}$

The technique of genioplasty with advancement of the genioglossus muscle in patients with mandibular retrognathism promotes increased posterior airspace (PAS) and soft tissue advancement of the mental region. ${ }^{19}$

The aim of this article was to assess whether any changes occur in the oropharyngeal size and in the position of both the hyoid bone and tongue after chin advancement surgery.

\section{MATERIAL AND METHODS}

This study was approved by the Ethics Committee of the Bahia Federal University (UFBA), under Opinion $n^{-}$40/09. The sample comprised 22 lateral cephalometric radiographs of 11 male and female individuals aged between 16 and 49 years, who were subjected to advancement genioplasty alone. The average chin advancement achieved in patients in this study was of $6.84 \mathrm{~mm} \pm 2.02 \mathrm{~mm}$. These procedures were carried out independently of the research. Eleven of these radiographs depicted the preoperative period $\left(\mathrm{T}_{0}\right)$ and 11 the postoperative period of at least four months $\left(\mathrm{T}_{1}\right)$ in order to prevent any potential postoperative swelling from interfering in the research outcomes. The radiographs were obtained 
with the patient's head immobilized by a cephalostat, orientated by the Frankfort horizontal plane positioned parallel to the floor and the midsagittal plane perpendicular to the floor. At the time when the radiographs were taken patients were instructed to keep their facial muscles at rest and not to swallow.

Initially, all 22 radiographs were scanned using an HP Scanjet G4050 TMA [Transparent Materials Adapter] (HP Development Company, L.P.) with slide scanning capabilities at 200 dpi with 100\% resolution. The images were exported to the Radiocef Studio $2.0^{\circledR}$

\begin{tabular}{|c|c|}
\hline $\begin{array}{l}\text { Cephalometric } \\
\text { landmarks }\end{array}$ & Description \\
\hline Porion (Po) & The most superior point of the external acoustic conduit \\
\hline Orbit (Or) & The most inferior point on the inferior margin of the orbit \\
\hline PNS & Point at the end of the posterior nasal spine \\
\hline Gonion (Go) & $\begin{array}{l}\text { Average of the inferior-most and posterior-most points of } \\
\text { the mandibular angle }\end{array}$ \\
\hline $\begin{array}{c}\text { Point B } \\
\text { (Supramentale) }\end{array}$ & The deepest point in mandibular alveolar process \\
\hline Pogonion (Pg): & $\begin{array}{l}\text { The most anterior point in the contour of the mandibular } \\
\text { symphysis }\end{array}$ \\
\hline Point C3 & The most anteroinferior point of the third cervical vertebra \\
\hline Point $\mathrm{H}$ & The most anterior superior point of the hyoid bone \\
\hline Point f1 & $\begin{array}{l}\text { Point located in the posterior wall of the pharynx, on the } \\
\text { B-Go line }\end{array}$ \\
\hline Point f2 & $\begin{array}{l}\text { Point located in the posterior wall of the tongue, on the } \\
\text { B-Go line }\end{array}$ \\
\hline Point D & $\begin{array}{l}\text { Point located over the PNS line perpendicular to the } \\
\text { Frankfort horizontal plane, forming part of the dorsum of } \\
\text { the tongue }\end{array}$ \\
\hline
\end{tabular}

Table 1 - Cephalometric landmarks used in the study and their description. software (Radio Memory Ltda., Belo Horizonte, MG, Brazil), and were analyzed with the Mixcef tool.

Subsequently, cephalometric landmarks were identified (Table 1). These landmarks determined the linear distances of the oropharyngeal space (f1-f2), which also revealed the anteroposterior changes in the tongue, vertical position of the tongue (D-PNS) and both the vertical position (H-SOPS) and horizontal position (C3-H) of the hyoid bone (Fig 1). These distances were automatically measured by the software.

Assessment of intra and inter-examiner agreement was conducted by means of remarking through the Radiocef Studio 2.0 ${ }^{\circledR}$ software (Radio Memory Ltda., Belo Horizonte, MG, Brazil the landmarks ) of five randomly selected radiographs by applying Lin's concordance correlation coefficient. One of the authors performed the tracings twice on the same radiograph, with a 15-day interval between them, and another examiner also marked the landmarks on the same five radiographs.

\section{STATISTICAL ANALYSIS}

Assessment of intra and inter-examiner agreement was performed by means of applying Lin's concordance correlation coefficient. Paired t test was used to assess the differences between pre- and postoperative measurements. Pearson's correlation was used to assess the correlation between the variables which yielded statistically significant differences and the amount of chin advancement. All test results for $\mathrm{p}$ values lower than 0.05 were considered statistically significant.
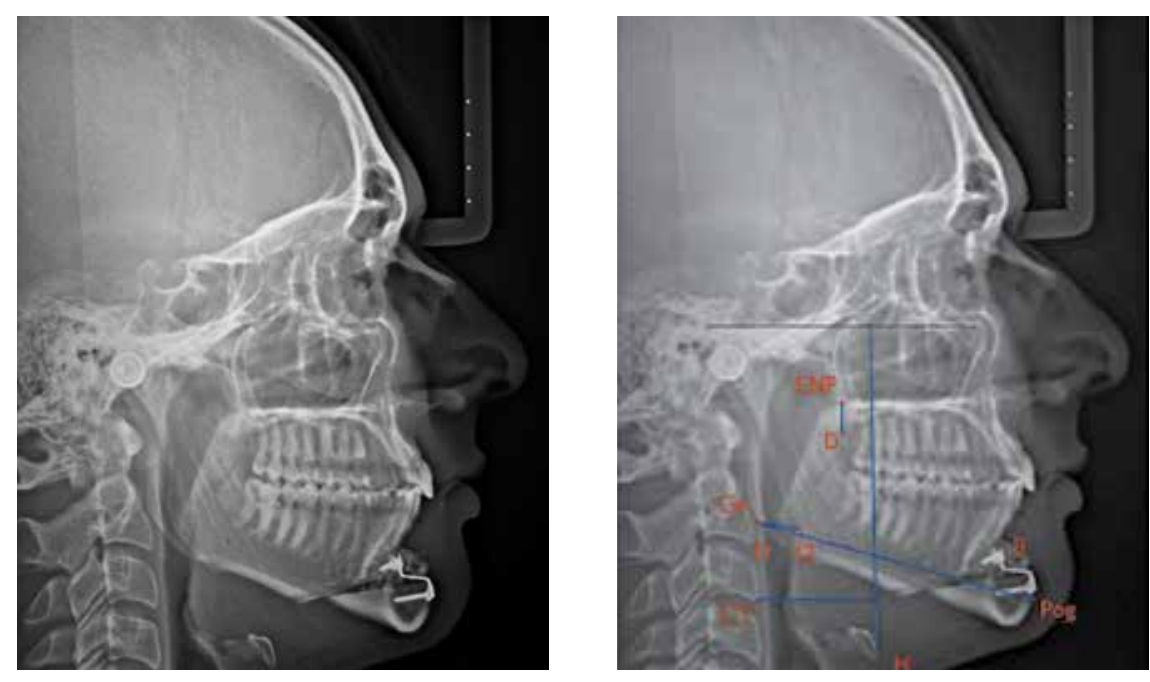

Figure 1 - Tracings performed with Radiocef software. 


\section{RESULTS}

A high degree of intraexaminer agreement (0.99) was found through the correlation coefficient between the measurements carried out by the researcher at two different times. A high degree of correlation was also found in the inter-examiner assessment, with a coefficient of 0.98 . Thus, no statistically significant difference was found for all measures assessed. In light of the results, the values of the first measurements were used for data analysis.

This study disclosed a statistically significant difference in the size of the oropharynx and in the positioning of the hyoid bone in the horizontal direction between both pre- and postoperative periods (Table 2). The oropharynx increased on average $1.83 \mathrm{~mm}$, pointing to a change in the position of the tongue anteriorly $(\mathrm{p}=0.01)$ and the hyoid bone moved forward on average $1.59 \mathrm{~mm}(\mathrm{p}=0.002)$.

In the vertical direction, the change in the hyoid bone and tongue $(\mathrm{p}=0.11)$ did not yield statistically significant results. Despite this, the hyoid bone proved to be more superior in over half of the sample $(p=0.61)$.

\section{DISCUSSION}

Lateral cephalometric radiographs were used because airspace dimensions as well as tongue and hyoid bone position are properly reproduced in cephalograms where the head is in a natural position. ${ }^{21} \mathrm{Al}-$ though radiographic cephalometry provides twodimensional images, it has been widely used in the study of pharyngeal airspace and craniofacial morphology as it offers considerable advantages, such as low cost and minimal exposure to radiation. ${ }^{8,9,17}$ Moreover, according to Barbosa et al, ${ }^{22}$ lateral cephalometric radiography is efficient in the diagnosis of adenoid hypertrophy because it strongly correlates with nasal endoscopy, which is considered the gold standard for diagnosing this condition.

Table 2 - Means of variables at $T_{0}$ and $T_{1}$

\begin{tabular}{cccc}
\hline & Before & After & \\
& Mean \pm SD & Mean \pm SD & p-value \\
\hline $\mathrm{f} 1-\mathrm{f} 2$ & $8.49 \pm 3.05$ & $10.33 \pm 3.12$ & 0.01 \\
\hline $\mathrm{C} 3-\mathrm{H}$ & $37.11 \pm 5.54$ & $38.33 \pm 5.85$ & 0.01 \\
\hline $\mathrm{S}-\mathrm{H}$ & $116.45 \pm 13.32$ & $116.71 \pm 13.45$ & 0.84 \\
\hline $\mathrm{D}-\mathrm{ENP}$ & $13.34 \pm 4.14$ & $12.00 \pm 3.84$ & 0.11 \\
\hline
\end{tabular}

The average value of the increase in the oropharynx, though small, can have great clinical significance because, according to Trotman et al, ${ }^{23}$ a decrease of $1 \mathrm{~mm}$ in diameter of the upper airway of a child can decrease effective airspace by $65 \%$, producing a critical obstruction.

Santos Júnior et al ${ }^{19}$ obtained results similar to ours in terms of oropharyngeal dimension and, consequently, the position of the tongue in the horizontal direction. They assessed pre- and postoperative lateral cephalometric radiographs of patients who had undergone genioplasty combined with nasal surgery or uvulopalatopharyngoplasty. The postoperative results, which varied between 4 and 6 months, showed a $2.9 \mathrm{~mm}$ mean increase in oropharyngeal space.

Mandibular advancement surgery has revealed an increase in the oropharyngeal size and has been recognized as one of the most successful procedures in the treatment of oropharyngeal space deficiency. ${ }^{7,16,17,25}$ According to Carlo et al, ${ }^{18}$ the principle underlying increases in oropharyngeal airspace is the fact that this surgery pulls the geniohyoid and genioglossus muscles forward, thereby causing an anterior movement of the tongue base and the hyoid bone and, consequently, increasing the posterior ${ }^{26}$ airspace. According to Ellis et $\mathrm{al},{ }^{5}$ in advancement genioplasty the tongue muscles, including geniohyoid and genioglossus muscles, must remain attached to the osteotomized bone segment in order to ensure adequate blood supply, minimizing the possibility of resorption and providing long-term stability. Preservation of the pedicle during surgery is responsible for the tongue moving anteriorly and this principle is not only embraced but advocated by other authors to this day. ${ }^{4,18,19,25,27}$

The findings of these research suggest the possibility that, with a relatively simple procedure. i.e., advancement genioplasty, one can expect an increase in oropharyngeal airspace as a result of the anterior repositioning of the base of the tongue and the hyoid bone, thereby

Table 3 - Correlation between the amount of chin advancement and the amount of oropharyngeal airspace increase and anterior repositioning of the hyoid bone.

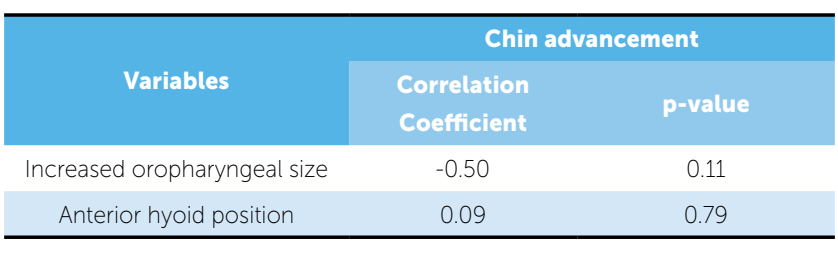

${ }^{1}$ Pearson's correlation 
improving both esthetic and functional conditions of patients with mandibular deficiency. Further studies must be conducted to assess the beneficial effect of this increase in oropharyngeal on breathing. By no means does chin advancement surgery replace mandibular advancement surgery, but it may be an alternative for some cases.

Ribeiro et $\mathrm{l}^{4}$ asserted that they failed to account for the amount of mandibular advancement when assessing changes in the same variables studied in this research, a factor that should have been taken into consideration. In this study, assessment of chin advancement alone did not disclose any correlation between the extent of the advancement and the amount of increase in oropharyngeal size $(p=0.11)$, nor between the extent of the advancement and the amount of anterior repositioning of the hyoid bone $(p=0.79)$ (Table 3). In other words, patients who experienced significant chin advancement did not necessarily attain considerable gains in the dimension of the oropharynx nor in anterior hyoid bone repositioning. These results can be explained by the continuous change in the position of the hyoid bone that occurs throughout one's lifetime, regardless of surgical interventions. These changes are age-related and differ in terms of facial pattern. ${ }^{28}$ In addition, since only the minimum period in which the surgery was performed was actually timed, the radiographs that depicted the postoperative period might present different time intervals. It is expected that further studies aimed at examining the variance between groups with different levels of advancement will show greater accuracy in the assessment of this correlation.

This investigation did not reveal any significant changes in the vertical position of the tongue and the hyoid bone. Athanasiou et $\mathrm{al}^{29}$ assessed tongue position after the use of a functional appliance for ante- rior mandibular repositioning. The authors found it to be more superiorly positioned. They argued that this change was due to increases in oral cavity space and the tendency of the tongue to occupy such space. For them, changes in the tongue occur whenever there is an increase in oral cavity size, which is not the case when advancement genioplasty is performed alone.

Santos Júnior et a ${ }^{19}$ showed a decrease of $2 \mathrm{~mm}$ on average in the vertical distance between the hyoid bone and the mandibular plane. This may have occurred because in addition to advancement genioplasty most of the sample was also subjected to uvulopalatopharyngoplasty (UPPP), which may have contributed to statistically significant outcomes.

Achilleos et $\mathrm{al}^{9}$ also showed that the hyoid bone took on a higher position after mandibular advancement surgery, in agreement with results obtained in other studies, ${ }^{8,16}$ in which its position remained unchanged in the long-term. When advancement genioplasty was performed alone, changes in the stomatognathic system proved less significant than in mandibular advancement surgery. Additionally, the sample size in this investigation $(\mathrm{n}=11)$ may have contributed to the attainment of this result. Thus, further studies using a larger sample size are warranted.

\section{CONCLUSIONS}

Based on the results of this study, it is reasonable to conclude that advancement genioplasty alone correlates with a statistically significant increase in the oropharyngeal size as a result of an anterior repositioning of the base of the tongue. Changes in the position of the hyoid bone in the horizontal direction were also observed, probably due to a stretching of the suprahyoid muscles resulting from chin advancement. 


\section{REFERENCES}

1. Ambrizzi DR, Franz SA, Pereira Filho VA, Gabrielli MAC, Gimenez CMM Bertoz FA. Avaliação das queixas estético-funcionais em pacientes portadores de deformidades dentofaciais. Rev Dental Press Ortod Ortop Facial. 2002:12(5):63-70

2. Freitas CE. Mentoplastia: um importante complemento, não uma solução In: Araújo A. Cirurgia Ortognática. São Paulo: Ed. Santos; 1999. cap. 12 p. 231-74.

3. Triaca A, Furrer T, Minoretti R. Chin shield osteotomy: a new genioplasty technique avoiding a deep mento-labial fold in order to increase the labial competence. Int J Oral Maxillofac Surg. 2009;38(11):1201-25

4. Proffit WR, Turvey TA, Moriarty JD. Augmentation genioplasty as an adjunct conservative orthodontic treatment. Am J Orthod. 1981;79(5):473-91.

5. Ellis III E, Dechou PC, McNamara JA Jr, Carlson DS, Liskiewicz WE. Advancement genioplasty with and without soft tissue pedicle: an experimental investigation. J Oral Maxillofac Surg. 1984;42(10):637-45.

6. Pinto PA, Ferreira AP, Figueredo A. Perspectiva ortodôntica da cirurgia do mento. Rev Portuguesa Estomatol Med Dent Cir Maxilofac. 2009:50(1):25-34

7. Ribeiro C. Efeitos da cirurgia ortognática de avanço ou recuo mandibular nas posições do osso hióide, da língua e no tamanho da orofaringe [dissertação]. Salvador (BA): Universidade Federal da Bahia; 2009.

8. Turnbull NR, Battagel JM. The effects of orthognathic surgery on pharyngeal airway dimensions and quality of sleep. Eur J Orthod. 2000:27(3):235-47.

9. Achilleos S, Krogstad O, Lyberg T. Surgical mandibular setback and changes in uvuloglossopharyngeal and head posture: a short and long-term cephamoletric study in males. Eur J Orthod. 2000;22(4):383-94.

10. Nuernberg $\mathrm{CHG}$, Vilella $\mathrm{OV}$. Avaliação cefalométrica da orofaringe. Rev Odonto Ciênc. 2006:21(54):370-5.

11. Pae EK, Blasius JJ, Nanda R. Heterogeneity in vertical positioning of the hyoid bone in relation to genioglossal in men. Angle Orthod 2004;74(3):343-48

12. Souza RP, Pagotto SR, Paes Junior AJO, Soares AH, Rapoport A. Diagnóstico por imagem da cavidade oral. Radiol Bras. 2003;36(3):169-72.

13. Guven $O$, Saraçoglu U. Changes in pharyngeal airway space and hyoid bone positions after body ostectomies and sagittal split ramus osteotomies. J Cranio Surg. 2005;16(1):23-30

14. Salles C, Campos OS, Andrade NA, Daltro C. Síndrome da apnéia e hipopnéia obstrutiva do sono: análise cefalométrica. Rev Bras Otorrinolaringol. 2005:71(3):369-72.

15. Baik UB, Suzuki M, Ikeda K, Sugawara J, Mitani H. Relationship between cephalometric characteristics and obstructive sites in obstructive sleep apnea syndrome. Angle Orthod. 2002;72(2):124-34
16. Gonçalves JR, Buschang PH, Gonçalves DG, Wolford LM. Postsurgical stability of oropharyngeal airway changes following counter-clockwise maxillo-mandibular advancement surgery. J Oral Maxillofac Surg. 2006;64(5):755-62

17. Pereira Filho VA, Jeremias F, Tedeschi L, Souza RF. Avaliação cefalométrica do espaço aéreo posterior em pacientes com oclusão Classe II submetidos à cirurgia ortognática. R Dental Press Ortodon Ortop Facial. 2007:12(5):119-25

18. Bruno Carlo B, Mauro P. Silvia B, Enrico S. Modified genioplasty and bimaxillary advancement for treating obstructive sleep apnea syndrome. J Oral Maxillofac Surg. 2008:66(9):1971-4.

19. Santos Junior JF, Abrahão M, Gregório LC, Zonato Al, Gumieiro EH. Mentoplastia para avanço do músculo genioglosso em pacientes com síndrome da apnéia-hipopnéia do sono obstrutiva e retrognatismo mandibular. Rev Bras Otorrinolaringol. 2007;73(4):480-6.

20. Heitz C, Lima LMS, Orso VA, Pinto LP, Ferreira AGM. Mentoplastia: do planejamento à técnica cirúrgica. J Bras Ortodon Ortop Facial. 2005:10(55):29-35.

21. Malkoc S, Usumez S, Nur M, Donaghy CE. Reproducibility of airway dimensions and tongue and hyoid positions on lateral cephalograms. Am J Orthod Dentofacial Orthop. 2005:128(4):513-6

22. Barbosa MC, Knop LAH, Lessa MM, Araújo TM. Avaliação da radiografia cefalométrica lateral como meio de diagnóstico da hipertrofia de adenóide. Rev Dental Press Ortod Ortop Facial. 2009:14(4):83-91

23. Trotman CA, MCNamara JA, Dibbets JM, Van der Weele LT. Association of lip posture and the dimensions of the tonsils and sagittal airway with facial morphology. Angle Orthod. 1997;67(6):425-32.

24. Trenouth MJ, Timms DJ. Relationship of functional oropharynx to craniofacial morphology. Angle Orthod. 1999;69(5):419-23.

25. Prinsell JR. Maxillomandibular advancement surgery for obstructive sleep apnea syndrome. J Am Dent. 2002;133(11):1489-97.

26. Strauss RA, Abubaker AO. Genioplasty: a case for advancement osteotomy J Oral Maxillofac Surg. 2000;58(7):783-87

27. Polido WD, Bell WH. Long-term osseous and soft tissue changes after large chin advancements. J Cranio-Maxillofac Surg. 1993;21(2):54-9

28. Pae EK, Quas C, Quas J, Garret N. Can facial type be used to predict changes in hyoid bone position with age? A perspective based on longitudinal data. Am J Orthod Dentofacial Orthop. 2008;134(6):792-7.

29. Athanasiou AE, Papadopoulos MA, Mazaheri M, Lagoudakis M. Cephalometric evaluation of pharynx, soft palate, adenoid tissue, tongue, and hyoid bone following the use of mandibular repositioning appliance in obstructive sleep apnea patients. Int J Adult Orthod Orthognath Sug. 1994; 9(2):273-83. 